\title{
Desorption Isotherms and Isosteric Heats of Fermented Cocoa Beans (Theobroma cocoa)
}

\author{
Djedjro C. Akmel ${ }^{1}$, Kouassi E. Kakou ${ }^{1}$, Kisselmina Y. Koné ${ }^{1}$, Nogbou E. Assidjo ${ }^{1}$ \& Patrice Kouamé $^{2}$ \\ ${ }^{1}$ Laboratoire des Procédés Industriels de Synthèses de l'Environnement et des Energies Nouvelles, Institut \\ National Polytechnique Félix Houphet Boigny (INP-HB), Yamoussoukro, Côte d'Ivoire \\ ${ }^{2}$ Laboratoire de Biochimie et des Procédés, Université Nangui Abroguoa (UNA), Abidjan, Côte d'Ivoire \\ Correspondence: Djedjro C. Akmel, Laboratoire des Procédés Industriels de Synthèses de l'Environnement et \\ des Energies Nouvelles, INP-HB, BP 1313 Yamoussoukro, Côte d'Ivoire. Tel: 225-0557-1021. E-mail: \\ akmeldc@gmail.com
}

Received: February 6, 2015 Accepted: March 27, 2015 Online Published: April 7, 2015

doi:10.5539/jfr.v4n3p138 URL: http://dx.doi.org/10.5539/jfr.v4n3p138

\begin{abstract}
Water desorption isotherms of fermented cocoa beans from Ivory Coast were determined using the gravimetric static method of saturated salts solutions at $30^{\circ} \mathrm{C}, 40{ }^{\circ} \mathrm{C}$ and $60{ }^{\circ} \mathrm{C}$, and isosteric heats of desorption were calculated from Clausius-Clapeyron equation. The experimental data were fitted to several isotherm equations. The best fittings were obtained for the BET equation for aw $<0.50$ (with an average mean relative deviation (MRD) value of $1.56 \%$ ) and for the Harkins-Jura equation for aw $\geq 0.50$ (with an average value MRD equation of $4.17 \%$ ). The isotherms obtained at $30{ }^{\circ} \mathrm{C}$ and $40{ }^{\circ} \mathrm{C}$ are practically coincident and overlapped for aw below 0.40 . Fermented cocoa beans presented a monolayer moisture content of 0.083 dry basis (d.b.) at $30^{\circ} \mathrm{C}$ and this value decreases with increasing temperature. The net isostheric heats of desorption for fermented cocoa beans for the temperature range studied $\left(30-60{ }^{\circ} \mathrm{C}\right)$ were estimated as a function of moisture content. The maximum net isosteric heat of desorption for fermented cocoa beans was estimated at around $13.51 \mathrm{~kJ} / \mathrm{mol}$ corresponding to a moisture content value of $2.85 \%$. The energy requirement for maintaining the moisture content low of $8.7 \%$ (d.b.) or $8 \%$ wet basis (w.b.) for safe storage of this product or for reducing the moisture content during drying was estimated at around $9.58 \mathrm{~kJ} / \mathrm{mol}$.
\end{abstract}

Keywords: cocoa beans, isostheric heat, mathematical model; water sorption isotherm

\section{Introduction}

Cocoa production is the main activity of smallholders. They provide $95 \%$ of the world production on surfaces lower than 10 ha with a weak average yield estimated from 350 to $400 \mathrm{~kg} / \mathrm{ha}$ cocoa beans (Barel, 2005). Ivory Coast is the world's largest cocoa grower. Its production represents 10\% of GDP (Gross Domestic Product) and $40 \%$ of export earnings (Banzio, 2003). However since some years, the quality of cocoa beans has decreased slowly and gradually on the world market. Quality of cocoa beans for export-market is significantly affected by post-harvest processing method (i.e. fermentation and drying) and the problems of cocoa beans stability during storage (Anonymous, 2006; Sandoval \& Barreiro, 2002; Fowler, 1995). In most cases the aerothermic conditions of storage area are unfavourable affecting beans moisture content and water activity. Water activity influences particularly micro-organisms growth, enzymatic reactions kinetic and the lipids oxidation in biological products. To maintain the stability of dried cocoa beans during storage, it is necessary to know product physical properties, in particular the relationship between water activity and equilibrium moisture content at room temperature and the relative humidity. This relationship is represented by product sorption isotherms. The effect of temperature on sorption isotherm is very important due to the fact that cocoa beans packaged in permeable jute bags are exposed to variable temperatures during storage and processing. In another hand, water activity changes with temperature (Al Muhtaseb, McMinn, \& Magee, 2002). Furthermore, sorption isotherm is used in drying to determine the final moisture (Cassini, Marczak, \& Norena, 2006; Noumi et al., 2004).

Unfortunately, few works is found in literature about water sorption isotherms of cocoa beans (Sandoval et al., 2002). Mercier, Tusa and Guaiquirian (1982) determined moisture desorption isotherms of cocoa beans at three temperatures $\left(33.3{ }^{\circ} \mathrm{C}, 41.8^{\circ} \mathrm{C}\right.$ and $\left.52.4{ }^{\circ} \mathrm{C}\right)$ using a gravimetric method. The monolayer water content and the average sorption enthalpy were calculated using the BET equation. Talib, Daud and Ibrahim (1995) determined 
moisture desorption isotherms of cocoa beans using a constant environment chamber for various combinations of air relative humidity (30 to $90 \%$ ) and temperature $\left(20^{\circ} \mathrm{C}\right.$ to $\left.70{ }^{\circ} \mathrm{C}\right)$. The new modified Hasley, Henderson, and Chung equations, whose parameters are fitted to a fifth-order polynomial with respect to temperature, was used to represent satisfactorily the isotherms of cocoa beans in the temperature range investigated.

Sandoval et al. (2002) obtained no statistical differences $(p<0.01)$ among the water sorption isotherms of non fermented cocoa beans (Venezuelan fine second grade) at $25{ }^{\circ} \mathrm{C}, 30^{\circ} \mathrm{C}$ and $35^{\circ} \mathrm{C}$. All data were adjusted with a single isotherm in this temperature range and the best fit were found for BET $(\mathrm{aw}<0.50)$ and Harking $-\mathrm{Jura}(\mathrm{aw} \geq$ $0.50)$ models.

More recently, GAB model gave the best fit of the sorption isotherms of cocoa and cupuassu products at $15{ }^{\circ} \mathrm{C}$, $30{ }^{\circ} \mathrm{C}$ and $35^{\circ} \mathrm{C}$ (Medeiros, 2006).

Although several mathematical models exist to describe water sorption isotherms of food materials (Iglesias, Chirife, \& Lombardi, 1975), none of them gives accurate results throughout the whole range of water activities, or for all types of foods.

The main purposes of this work were to provide experimental data for the sorption characteristics of fermented cocoa beans originated from Ivory Coast to model the desorption isotherms, determine their dependence on temperature, and estimate the differential heat of sorption which is importance when designing equipment for dehydration processes of cocoa beans.

\section{Material and Methods}

\subsection{Material}

The experiments were achieved on fresh cocoa beans previously fermented. About $20 \mathrm{~kg}$ fermented cocoa beans with an initial moisture content around $55-60 \%$ (by wet weight) supplied by an organic agricultural farm were used.

\subsection{Measurement of Water Sorption Isotherms}

The method for determining water desorption isotherms was static gravimetric technique in which the weights were followed discontinuously until the equilibrium. This method was based on the COST 90 project method (Wolf, Spiess, \& Jung, 1985). About $25 \pm 0.001 \mathrm{~g}$ sample of cocoa beans was put in an open shallow glass container inside a glass jar containing diluted solutions of sulphuric acid. Each experiment was carried out in triplicate. Sulphuric acid (Fisher Scientific, UK) solutions were used to maintain the specified relative humidity inside the glass jars.

The glass jars with the samples were kept in temperature-controlled cabinets $\left( \pm 0.5{ }^{\circ} \mathrm{C}\right)$ at $30{ }^{\circ} \mathrm{C}, 40{ }^{\circ} \mathrm{C}$ and $60^{\circ} \mathrm{C}$. The samples were allowed to equilibrate until there was no discernible weight change, as evidenced by constant weight values $( \pm 0.001 \mathrm{~g})$. This involved a period of approximately $9-12$ days for $60{ }^{\circ} \mathrm{C}, 15-21$ days for $40^{\circ} \mathrm{C}$ and $21-27$ days for $30^{\circ} \mathrm{C}$. The long stabilization time of samples constitutes main disadvantage of this method (Medeiros, Ayrosa, Pitombo, \& Lannes, 2006). To prevent microbial spoilage of samples, a small dish containing crystalline tymol was placed in the glass jar where high water activities occurred $\left(a_{w}>0.7\right)$ (Wolf et al., 1985; Cassini et al., 2006). In order to avoid disrupting the degree of atmospheric moisture sorption, the sample was weighted only every third day in five seconds or less. After the equilibrium had been reached, the samples were dried using the oven method at $105{ }^{\circ} \mathrm{C}$ during $24 \mathrm{~h}$ (AOAC, 1990; Augier, 1999). Moisture determinations were done by triplicate and the averages were calculated. Seven (7) equilibrium points were obtained in these experiments.

The isotherm models used to fit the data are presented in Table 1. The goodness of fit of each model was evaluated using the correlation coefficient ( $r$ ) and the mean relative deviation (MRD). The MRD value is given in percentage and may be estimated as follows:

$$
\operatorname{MRD}(\%)=\frac{100}{N} \sum_{i=1}^{N} \frac{\left|X_{E x p, i}-X_{C a l, i}\right|}{X_{E x p, i}}
$$

where values below $10 \%$ are indicative of good fit (Lomauro, Bakshi, \& Labuza., 1985). 
Table 1. Isotherm equations for experimental data fitting

\begin{tabular}{|c|c|c|c|}
\hline Model & Mathematical expression & & $a_{w}$ range \\
\hline $\begin{array}{l}\text { BET (Brunauer et al., } \\
1938 \text { ) }\end{array}$ & $X_{e q}=X_{m} C a_{w} /\left[\left(1-a_{w}\right)\left(1+(C-1) a_{w}\right)\right]$ & (1) & $a_{w}<0.50$ \\
\hline $\begin{array}{l}\text { GAB (Van den Ben \& } \\
\text { Bruin, 1981) }\end{array}$ & $\begin{array}{c}X_{e q}=X_{m} C K a_{w} /\left[\left(1-K a_{w}\right)\left(1+C_{G} K a_{w}-K a_{w}\right)\right] \\
C=c_{0} \exp \left(\Delta H_{C} / R T\right) \\
K=k_{0} \exp \left(\Delta H_{K} / R T\right)\end{array}$ & $\begin{array}{l}\text { (3) } \\
\text { (4) }\end{array}$ & $0.05<a_{w}<0.95$ \\
\hline Chung and Pfost (1967) & $X_{e q}=\frac{1}{B}\left[\ln A-\ln \left(-\ln a_{w}\right)\right]$ & $(5)$ & $0.20<a_{w}<0.90$ \\
\hline Hasley (1948) & $X_{e q}=\left(-A / \ln a_{w}\right)^{\frac{1}{B}}$ & (6) & $0.05<a_{w}<0.80$ \\
\hline Harkins and Jura (1946). & $X_{e q}=\left[-B /\left(\ln \left(a_{w}\right)-A\right)\right]^{\frac{1}{2}}$ & (7) & $a_{w}>0.50$ \\
\hline Henderson (1952) & $X_{e q}=\left[-\ln \left(1-a_{w}\right) / A\right]^{\frac{1}{B}}$ & (8) & $0.50<a_{w}<0.95$ \\
\hline $\begin{array}{l}\text { Kuhn (Labuza, Mizrahi, \& } \\
\text { Kasel, 1972).) }\end{array}$ & $X_{e q}=A / \ln a_{w}+B$ & (9) & $a_{w}<0.5$ \\
\hline Oswin (1946) & $X_{e q}=A\left[a_{w} /\left(1-a_{w}\right)\right]^{B}$ & $(10)$ & $0.05<a_{w}<0.90$ \\
\hline Smith (1947) & $X_{e q}=A+B \ln \left(1-a_{w}\right)$ & (11) & $0.50<a_{w}<0.95$ \\
\hline Freundlich (1906) & $X_{e q}=A\left(a_{w}\right)^{\frac{1}{B}}$ & (12) & $a_{w}<0.90$ \\
\hline
\end{tabular}

Variables to measure experimentally: $X_{e q}=$ equilibrium moisture content (\% d.b.); $T=$ temperature $(\mathrm{K}) ; a_{w}=$ water activity.

Parameters to be estimated from the data: $A=$ constant (dimensionless), $B=$ constant (dimensionless), $C=\mathrm{GAB}$ or BET model parameter (dimensionless), $c_{0}=$ constant (adjusted to the temperature effect) (dimensionless), $\Delta H_{C}=$ difference in enthalpy between mono-layer and multi-layer sorption $(\mathrm{Kj} / \mathrm{mol}), \Delta H_{K}=$ difference between the heat of condensation of water and the heat of sorption of the multilayer $(\mathrm{Kj} / \mathrm{mol}), K=\mathrm{GAB}$ model parameter (dimensionless), $k_{0}=$ constant (adjusted to the temperature effect) (dimensionless), $R=$ universal gas constant $(0.00831 \mathrm{Kj} /(\mathrm{mol} . \mathrm{K})), X m=$ Monolayer moisture content $(\%$ d.b.).

\subsection{Measurement of Net Isosteric Heats}

The net isosteric heat of desorption $\left(q_{s t}\right)$ was calculated from the Clausius-Clayperon equation (Labuza, Kaanane, \& Chen, 1985; Tsami, 1991; Hossain, Bala, Hossain, \& Mondol, 2001; Veltchev \& Menkov, 2000; Igbabul, Ariahu, \& Umeh, 2013): 


$$
q_{s t}=-R\left(\frac{\partial \ln \left(a_{w}\right)}{\partial(1 / T)}\right)
$$

where $T$ is the absolute temperature (K) and $R$ is the universal gas constant $(0.00831 \mathrm{Kj} /(\mathrm{mol} . \mathrm{K}))$ and $a_{w}$ is the water activity.

This relationship required previously that sorption isotherms were determined at the study temperatures, in order to calculate the logarithmic variation in water activity as a function of temperature inverse at constant moisture content. In practice, it is easier to determine the slope of regression lines $\ln \left(a_{w}\right) v s 1 / T$ for a specific moisture content, and then deduce the net isosteric heat of sorption $\left(q_{s t}\right)$.

The heat of desorption is a measure of the energy requirement to break the intermolecular forces between water vapour molecules and adsorbent surface (AL-Muhtaseb et al., 2002; Rao \& Rizvi, 1995 ).

In an attempt to describe the relationship between the net isosteric heat of sorption and the equilibrium moisture content, Tsami, Maroulis, Morunos and Saravacos.(1990) proposed an empirical exponential correlation, which can be written as:

$$
q_{s t}=q_{0} \exp \left(-X / X_{0}\right)
$$

where $q_{0}$ is the net isosteric heat of sorption of the first molecules of water in the food and $X_{0}$ is the characteristic moisture content of food material. The values of $q_{0}$ and $X_{0}$ were determined by adjustment of net isosteric heat $q_{s t}$ data with the Equation (15).

\section{Results and Discussion}

\subsection{Water Sorption Isotherms}

The experimental data obtained for water desorption isotherms of fermented cocoa beans at $30{ }^{\circ} \mathrm{C}, 40{ }^{\circ} \mathrm{C}$ and $60{ }^{\circ} \mathrm{C}$ are shown in Figure 1. The desorption isotherms reveal an increase in equilibrium moisture content with increasing water activity, at a constant temperature. The effect of temperature on desorption isotherm for the total range of water activities can be observed. The Figure 1 shows clearly that the moisture contents decrease while the temperature increases at constant water activity. This behavior is typical of many food products (Vazquez, Chenlo \& Moreira, 2003). Moisture sorption isotherms of most foods are nonlinear, generally sigmoidal in shape, and have been classified as Type II isotherms (Akkad et al., 2008; AL-Muhtaseb et al., 2002; Sandoval et al., 2002; Kouhila, Belghit, \& Daguenet, 1999).

The isotherms obtained at $30^{\circ} \mathrm{C}$ and $40{ }^{\circ} \mathrm{C}$ are practically coincident and overlapped for aw below 0.40 . Indeed many researchers have observed that the sorption isotherms vary very little for temperature differences lower than $10^{\circ} \mathrm{C}$. A similar behavior was observed for non fermented cocoa beans at $25^{\circ} \mathrm{C}$ to $35^{\circ} \mathrm{C}$ (Sandoval et al., 2002), for sultana raisin at $20^{\circ} \mathrm{C}$ to $30^{\circ} \mathrm{C}$ (Saravacos, Tsiourvas, \& Tsami, 1986).

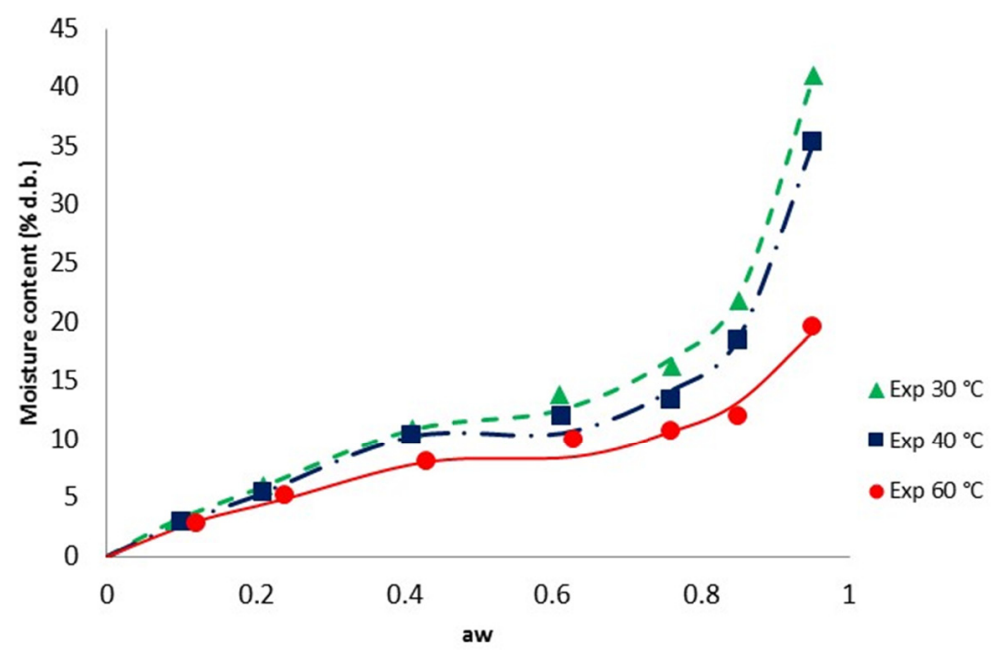

Figure 1. Desorption isotherms of fermented cocoa beans at different temperatures 
Table 2 shows the fitting constants of models (presented in table 1), the correlation coefficient (r) and the mean relative deviation (MRD).

Table 2. Estimated values of constants, correlation coefficient (r) and the mean relative percentage deviation modulus (MRD) obtained for the models

\begin{tabular}{|c|c|c|c|c|}
\hline Model & Constants & $30{ }^{\circ} \mathrm{C}$ & $40^{\circ} \mathrm{C}$ & $60^{\circ} \mathrm{C}$ \\
\hline \multirow[t]{5}{*}{ GAB } & $\mathrm{Xm}$ & 0.0543 & 0.0455 & 0.0464 \\
\hline & $\mathrm{C}$ & 27.0155 & 44.0684 & 22.5443 \\
\hline & K & 0.9117 & 0.9151 & 0.7930 \\
\hline & $\mathrm{r}$ & 0.990 & 0.985 & 0.972 \\
\hline & $\operatorname{MRD}(\%)$ & 14.30 & 16.46 & 13.27 \\
\hline \multirow[t]{4}{*}{ BET } & $\mathrm{Xm}$ & 0.0828 & 0.0822 & 0.0554 \\
\hline & $\mathrm{C}$ & 5.0030 & 4.1163 & 6.5404 \\
\hline & $\mathrm{r}$ & $>0.999$ & $>0.999$ & 0.997 \\
\hline & MRD(\%) & 0.24 & 0.64 & 3.81 \\
\hline \multirow[t]{4}{*}{ Chung-Pfost } & A & 2.3626 & 2.4923 & 3.2081 \\
\hline & B & 8.8321 & 10.5798 & 17.4761 \\
\hline & $\mathrm{r}$ & 0.883 & 0.868 & 0.962 \\
\hline & $\operatorname{MRD}(\%)$ & 32.71 & 31.82 & 10.88 \\
\hline \multirow[t]{4}{*}{ Hasley } & A & 0.1436 & 0.1439 & 0.1442 \\
\hline & B & 1.7608 & 1.7510 & 1.7595 \\
\hline & $\mathrm{r}$ & 0.972 & 0.955 & 0.910 \\
\hline & $\operatorname{MRD}(\%)$ & 339.29 & 393.60 & 519.41 \\
\hline \multirow[t]{4}{*}{ Harkins-Jura } & A & -0.0051 & -0.0080 & 0.049420715 \\
\hline & B & 0.0077 & 0.0054 & 0.0037 \\
\hline & $\mathrm{r}$ & 0.998 & 0.996 & 0.970 \\
\hline & MRD(\%) & 3.85 & 4.77 & 3.90 \\
\hline \multirow[t]{4}{*}{ Henderson } & $\bar{A}$ & 8.4469 & 10.2375 & 58.2966 \\
\hline & B & 1.0830 & 1.1008 & 1.7338 \\
\hline & $\mathrm{r}$ & 0.979 & 0.969 & 0.974 \\
\hline & $\operatorname{MRD}(\%)$ & 23.02 & 24.74 & 9.73 \\
\hline \multirow[t]{4}{*}{ Kuhn } & $\bar{A}$ & -0.1103 & -0.1071 & -0.0708 \\
\hline & B & -0.0137 & -0.0163 & -0.0025 \\
\hline & $\mathrm{r}$ & 0.998 & 0.999 & 0.989 \\
\hline & MRD(\%) & 7.51 & 2.58 & 6.81 \\
\hline \multirow[t]{4}{*}{ Oswin } & $\bar{A}$ & 0.1050 & 0.0844 & 0.0752 \\
\hline & B & 0.4568 & 0.4864 & 0.3191 \\
\hline & $\mathrm{r}$ & 0.995 & 0.990 & 0.985 \\
\hline & MRD & 9.86 & 11.13 & 11.54 \\
\hline \multirow[t]{4}{*}{ Smith } & A & 0.0222 & 0.0220 & 0.0361 \\
\hline & B & -0.1199 & -0.1012 & -0.0516 \\
\hline & $\mathrm{r}$ & 0.982 & 0.926 & 0.976 \\
\hline & MRD & 13.15 & 14.89 & 14.70 \\
\hline \multirow[t]{4}{*}{ Freundlich } & $\bar{A}$ & 0.3939 & 0.3311 & 0.1673 \\
\hline & B & 0.4440 & 0.4655 & 1.0183 \\
\hline & $\mathrm{r}$ & 0.934 & 0.917 & 0.925 \\
\hline & MRD & 43.29 & 43.74 & 17.05 \\
\hline
\end{tabular}


All models present correlation coefficient very close to unity indicating good fit to experimental data. However, considering the MRD, the best fittings were obtained for the BET equation for $\mathrm{a}_{\mathrm{w}}<0.50$ (with an average value of $1.56 \%$ ) and for the Harkins-Jura equation for $\mathrm{a}_{\mathrm{w}} \geq 0.50$ (with an average value of $4.17 \%$ ). The isotherms graphical representation at $30^{\circ} \mathrm{C}, 40{ }^{\circ} \mathrm{C}$ and $60{ }^{\circ} \mathrm{C}$ with these equations and experimental data are presented in Figure 1 Sandoval et al. (2002) reported that the BET equation $\left(a_{\mathrm{w}}<0.50\right)$ and the Harkins-Jura equation $\left(\mathrm{a}_{\mathrm{w}} \geq 0.5\right)$ provide good description of cocoa beans isotherms.

The fittings of these equations to experimental data generated the lowest MRD values, due probably, to the fact that these equations describe water sorption isotherms of food materials in limited range of water activities where as some models are involved in overall range. Labuza (1975) noted that no sorption isotherm model could fit data over the entire range of water activities because water is associated to food matrix by different mechanisms in different water activity regions. Furthermore Iglesias and Chirife (1982) recommended to divide in two domains the water activities range to realize sorption isotherms of food materials.

Using the Harkins-Jura equations, the high values of moisture contents, corresponding to a water activity of 0.70 , for which cocoa beans remained safe for microbiological stability after drying or in storage, were $14.83 \%$, $12.47 \%$ and $9.56 \%$ at $30{ }^{\circ} \mathrm{C}, 40{ }^{\circ} \mathrm{C}$ and $60{ }^{\circ} \mathrm{C}$, respectively. Different studies reported adsorption and/or desorption isotherms of cocoa beans (Cassini et al., 2006; Sandoval et al., 2002; Talib et al., 1995). Concerning desorption isotherms of fermented cocoa beans, the values estimated from the data presented by Talib et al. (2002) for the same water activity value were $26.56 \%, 18.52 \%$ and $11.09 \%$ at $30{ }^{\circ} \mathrm{C}, 40{ }^{\circ} \mathrm{C}$ and $60{ }^{\circ} \mathrm{C}$, respectively. These values of moisture contents were higher than the results obtained herein at the same temperatures. This could be explained by the excessive initial moisture content of cocoa beans used by these researchers for their experimentation.

The monolayer moisture content values (Xm) of fermented cocoa beans estimated with BET equation at $30{ }^{\circ} \mathrm{C}$, $40{ }^{\circ} \mathrm{C}$ and $60{ }^{\circ} \mathrm{C}$ can observed in Table 3. Fermented cocoa beans presented a monolayer moisture content of 0.083 (d.b.) at $30^{\circ} \mathrm{C}$ and this value decreases with increasing temperature. This fact on $\mathrm{Xm}$ is a characteristic of type II isotherms. Similar results were found by others researchers for protein (Cassini et al., 2006), for starch powders (AL-Muhtaseb et al., 2002) and for tomatoes (McLaughlin \& Magee, 1998). This decrease in monolayer moisture content reflects the reduction in product's hygroscopicity which accompanies the increasing temperature. This can be explained by the reduction of the degree of hydrogen bonding in such products with the increasing temperature, thereby decreasing the availability of active sites for water binding and thus, the monolayer moisture content (AL-Muhtaseb et al., 2002).

Considering the values of monolayer moisture content estimated with BET equation, a more detailed analysis of GAB parameters can provide further valuable information about desorption. Therefore a direct non-linear regression technique was adopted, with Equations 3 and 4 being substituted into Equation 2. The results of regression analysis are summarized in Table 3 . These parameters $\left(\mathrm{c}_{0}, \Delta \mathrm{H}_{\mathrm{C}}, \mathrm{k}_{0}\right.$ and $\left.\Delta \mathrm{H}_{\mathrm{K}}\right)$ have also physical meaning in terms of sorption processes (Van den Berg, 1984). $\Delta H_{C}$ represents the difference in enthalpy between mono-layer and multi-layer sorption (Van den Berg, 1984). The values of $\Delta H_{C}$ are negatives (with an average value of $-25.125 \mathrm{Kj} / \mathrm{mol}$ ). These negative values show that the reaction of the water removal associated with the food matrix is endothermic. This indicates the need to bring energy to achieve the optimum moisture content of the food, for which stability is maximum. For some authors (Brunauer et al., 1938; Rockland, 196.), this optimum moisture content corresponds to the mono-layer moisture content of BET. $\Delta H_{K}$ represents the difference between the heat of condensation of water and the heat of sorption of the multi-layer (Van den Berg, 1984). The positive value of $\Delta H_{K}$ indicates that the heat of sorption of the multi-layer is lower than the heat of condensation of water, in the case of fermented cocoa beans.

Table 3. Characteristic GAB parameters for Equation 3 and Equation 4 at different temperatures

\begin{tabular}{llllllll}
\hline $\mathrm{T}\left({ }^{\circ} \mathrm{C}\right)$ & $\mathrm{Xm}$ & $\mathrm{c} 0$ & $\Delta \mathrm{H}_{\mathrm{C}}(\mathrm{Kj} / \mathrm{mol})$ & $\mathrm{k} 0$ & $\Delta \mathrm{H}_{\mathrm{K}}(\mathrm{Kj} / \mathrm{mol})$ & $\mathrm{r}$ & $\mathrm{MRD}(\%)$ \\
\hline $30^{\circ} \mathrm{C}$ & 0.083 & 9057.49 & -24.331 & 0.285 & 2.843 & 0.985 & 18.97 \\
$40^{\circ} \mathrm{C}$ & 0.082 & 8956.29 & -25.514 & 0.198 & 3.838 & 0.977 & 19.36 \\
$60^{\circ} \mathrm{C}$ & 0.055 & 8871.27 & -25.531 & 0.195 & 3.946 & 0.966 & 16.90 \\
\hline
\end{tabular}

$c_{0}=$ constant (adjusted to the temperature effect) (dimensionless), $\Delta H_{C}=$ difference in enthalpy between mono-layer and multi-layer sorption $(\mathrm{Kj} / \mathrm{mol}), \Delta H_{K}=$ difference between the heat of condensation of water and the heat of sorption of the multi-layer $(\mathrm{Kj} / \mathrm{mol}), k_{0}=$ constant (adjusted to the temperature effect) (dimensionless), $X m=$ Monolayer moisture content (d.b.). 


\subsection{Net Isosteric Heats of Desorption}

A graphical representation of the net isostheric heats of desorption for fermented cocoa beans is shown in Figure 2. The results illustrate a progressive increase in the heat of desorption with decreasing moisture content. Our results agrees with observations by many researchers (Cassini et al., 2006; Magda, Ana, Ronaldo, \& Suzana, 2006; Fasina \& Sokhansanj, 1993), since the lower the moisture content, the higher the energy required to remove water from product.

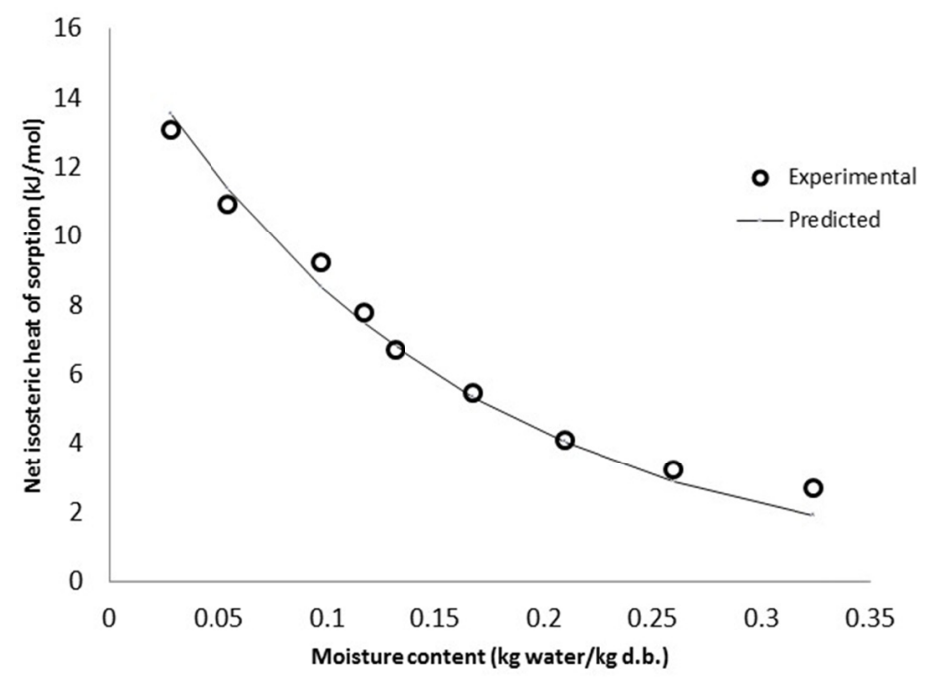

Figure 2. Net Isosteric heat of sorption of fermented cocoa beans estimated between 30 and $60{ }^{\circ} \mathrm{C}$

The net isosteric heats of sorption have been modeled by an empirical exponential correlation given by Tsami et al. (1990):

$$
q_{s t}=16.34 \exp (-X / 0.15) \quad \text { (with } \mathrm{r}=0.996 \text { and } \mathrm{MRD}=18.89 \% \text { ). }
$$

Thus, the maximum net desorption isosteric heat of fermented cocoa beans was estimated at around $13.51 \mathrm{~kJ} / \mathrm{mol}$ corresponding to a moisture content value of $2.85 \%$.

The energy required for maintaining the moisture content at $8.7 \%$ (d.b.) or $8 \%$ (w.b.) for safe storage of this product (Braudeau, 1970) or for reducing the moisture content during drying was estimated at around $9.58 \mathrm{~kJ} / \mathrm{mol}$.

\section{Conclusions}

The experimental data for water desorption isotherms of fermented cocoa beans (Ivory Coast) were determined for three temperatures $\left(30^{\circ} \mathrm{C} ; 40{ }^{\circ} \mathrm{C}\right.$ and $\left.60{ }^{\circ} \mathrm{C}\right)$ and adjusted to several equations. Considering the MRD, the best fittings were obtained for the BET equation for $\mathrm{a}_{\mathrm{w}}<0.50$ (with an average value of $1.56 \%$ ) and for the Harkins-Jura equation for $\mathrm{a}_{\mathrm{w}} \geq 0.50$ (with an average value equation of $4.17 \%$ ). Using the Harkins-Jura equation, the values of moistures contents considering safe for microbiological stability $\left(\mathrm{a}_{\mathrm{w}}=0.70\right)$ were deduced at each temperature studied. Fermented cocoa beans presented a monolayer moisture content of 0.083 (d.b.) at $30{ }^{\circ} \mathrm{C}$ and this value decreases with increasing temperature.

The net isostheric heats of desorption for fermented cocoa beans for the temperature range studied $\left(30-60{ }^{\circ} \mathrm{C}\right)$ were estimated as a function of moisture content. The energy requirement for maintaining the moisture content at $8.7 \%$ (d.b.) or $8 \%$ (w.b.) for safe storage of this product or for reducing the moisture content during drying was estimated at around $9.58 \mathrm{~kJ} / \mathrm{mol}$.

\section{Acknowledgements}

The authors gratefully acknowledge the agricultural cooperative of cocoa farmers Yamoussoukro (ECOYA) for providing the fermented cocoa beans, and the Coffee-Cocoa Stock Exchange from Ivory Coast (BCC) for providing financial support.

The Department of Chemical Engineering and Agri-food of INP-HB Yamoussoukro also is gratefully 
acknowledged for providing the products and equipement necessary for this study.

\section{References}

Akkad, S., Idlimam, A., Lamharrar, A., Essaber, M., Kouhila, M., \& Costa, J. (2008). Evaluation des isothermes de désorption et de la chaleur isosthérique de deux plantes aromatiques et médicinales par la méthode gravimetrique statique en vue de leur séchage. Revue des Energies Renouvelables SMST 08 Alger, 1-6.

AL-Muhtaseb, A. H., McMinn, W. A. M., \& Magee, T. R. A. (2002). Moisture sorption isotherm characteristics of food products: A review. Trans IChemE, 80(2), 118-128. http://dx.doi.org/10.1205/09603080252938753

Anonymous. (2006). Elaboration d'un plan national qualité café cacao: Etude diagnostique. Rapport final, Bourse du café et du cacao (BCC) (p. 60), Abidjan.

AOAC. (1990). Association of Official Analytical Chemists. Official Methods of Analysis: 930.04. Moisture content in plants, 1, p. 949.

Basunia, M. A., \& Abe, T. (2001). Moisture desorption isotherms of medium-grain rough rice. Journal of Stored Products Research, 37, 205-219. http://dx.doi.org/10.1016/S0022-474X(00)00022-9

Augier, F. (1999). Transport d'eau et d'acide en milieu complexe- Application au séchage de la fève de cacao. Thèse de doctorat, Université Montpellier II, p. 187

Banzio, D. (2003). Comprendre et opérer dans les filières café et cacao en dix modules (pp. 10-23). Abidjan.

Barel, M. (2005). Le commerce du cacao dans le monde. Cirad, Chocolat et confiserie. Magazine n 410.

Braudeau, J. (1970). EL Cacao. Editorial Blume, Barcelona, Spain

Brunauer, S., Emmet, P. H., \& Teller, E. (1938). Adsorption of gases in multi-molocular layers. Journal of American Chemical Society, 60, 309-319. http://dx.doi.org/10.1021/ja01269a023

Cassini, A. S., Marczak, L. D. F., \& Norena, C. P. Z. (2006). Water adsorption isotherms of texturized soy protein. Journal of Food Engineering, 77, 194-199. http://dx.doi.org/10.1016/j.jfoodeng.2005.05.059

Chung, D. S., \& Pfost, H. B. (1967). Adsorption and desorption of water vapor by cereal grains and their products. Transactions of the ASABE, 10(4), 549-557. http://dx.doi.org/10.13031/2013.39726

Fasina, O. O., \& Sokhansanj, S. (1993). Equilibrium moisture relations and heat of sorption of Alfafa Pellets. Journal of Agriculture Engineering Research, 56, 51-63. http://dx.doi.org/10.1006/jaer.1993.1060

Fowler, M. S. (1995). Quality of cocoa beans for chocolate manufacturers (pp. 147-153). Seminar Proceedings, Montpellier.

Freundlich, H. M. F. (1906). Uber die adsorption in losungen. Zeitschrift fur Physikalishe Chemie, 57(A), $385-470$.

Halsey, G. (1948). Physical adsorption on non-uniform surfaces. Journal of Chemistry Physics, 16, 931-937. http://dx.doi.org/10.1063/1.1746689

Harkins, W. D., \& Jura, G. (1946). Surfaces of Solids. XII. An Absolute Method for the Determination of the Area of a Finely Divided Crystalline Solid. Journal of American Chemical Society, 68, 1941. http://dx.doi.org/10.1021/ja01236a047

Henderson, S. M. (1952). A basic concept of equilibrium moisture. Agricultural Engineering, 33, 29-33.

Hossain, M. D., Bala, B. K., Hossain, M. A., \& Mondol, M. R. A. (2001). Sorption Isotherms and Heat of Sorption of Pineapple. Journal of Food Engineering, 48(2), 103-107. http://dx.doi.org/10.1016/S0260-8774(00)00132-1

Igbabul, B. D., Ariahu, C. C., \& Umeh, E. U. (2013). Moisture Adsorption Isotherms of African Arrowroot Lily (Taccainvolucrata) Tuber Mash as Influenced by Blanching and Natural Fermentation. Journal of Food Research, 2(3), 79-92. http://dx.doi.org/10.5539/jfr.v2n3p79

Iglesias H. A., \& Chirife J. (1982). Handbook of food isotherms water sorption. Parameters for food and food components. New York: Academic Press. http://dx.doi.org/10.1016/B978-0-12-370380-4.50006-2

Iglesias, H. A., \& Chirife, J. (1976). Isosteric heats of water vapour sorption on dehydrated foods. Part I. Analysis of differential heat curves. Lebensm. -Wiss.- Technol, 9, 116-122.

Iglesias, H. A., Chirife, J., \& Lombardi, J. L. (1975). Comparison of water vapour sorption by sugar beet root $\begin{array}{lllll}\text { components. Journal } & \text { Food }\end{array}$ 
http://dx.doi.org/10.1111/j.1365-2621.1975.tb00044.x

Kouhila, M., Belghit, A., \& Daguenet, M. (1999). Approche experimentale des isothermes de sorption de la menthe en vue du séchage par énergie solaire. Revues des energies renouvelables, 2(1), 61-68.

Labuza, T. P., Kaanane, A., \& Chen, J.vY. (1985). Effect of Temperature on the Moisture Sorption Isotherms and Water Activity Shift of Two Dehydrates Foods. Journal of Food Science, 50, 38-391. http://dx.doi.org/10.1111/j.1365-2621.1985.tb13409.x

Labuza, T. P., Mizrahi, S., \& Kasel, M. (1972). Mathématical model for optimization of flexible film packaging of foods for storage. Trans. ASAE, 15, 150. http://dx.doi.org/10.13031/2013.37853

Labuza, T. P. (1975). Interpretation of sorption data in relation to the state of constituent water. In R. B. Duckworth (Ed.), Water Relations of Food (pp. 155-172). New York, USA: Academic Press. http://dx.doi.org/10.1016/B978-0-12-223150-6.50014-6

Lomauro, C. J., Bakshi, A. S., \& Labuza, T. P. (1985). Evaluation of food moisture sorption isotherm equations part I: Fruit, vegetable and meat products. Food Science and Technology, 18(2), 111-117.

Magda, L. M., Ana, M. I. B. A., Ronaldo, N. M. P., \& Suzana, C. S. L. (2006). Sorption isotherms of cocoa and cupuassu products. Journal of Food Engineering, 77, 194-199. http://dx.doi.org/10.1016/j.jfoodeng.2005.02.002

McLaughlin, C. P., \& Magee, T. R. A. (1998). The determination of sorption isotherm and the isosteric heats of sorption for potatoes. Journal of Food Engineering, 35, 267-280. http://dx.doi.org/10.1016/S0260-8774(98)00025-9

Medeiros, M. L., Ayrosa, A. M. I. B., Pitombo, R. N. M., \& Lannes, S. C. S. (2006). Sorption isotherms of cocoa and cupuassu products. Journal of Food Engineering, 73, 402-406. http://dx.doi.org/10.1016/j.jfoodeng.2005.02.002

Mercier, P., Tusa, A., \& Guaiquirian, H. (1982). Adsorcion del agua en semilla de café y cacao. Acta Cientifica Venezolana, 33(1), 398.

Noumi, G. B., Laurent, S., Ngameni, E., Kapseu, C., Jannot, Y., \& Permentier, M. (2004). Modélisation de la deshydratation de la pulpe des fruits du Canarium schweinfurthii Engl,. Tropicultura, 22(2), 70-76.

Noumi, G. B., Laurent, S., Ngameni, E., Kapseu, C., Jannot, Y., \& Permentier, M. (2004). Modélisation de la déshydratation de la pulpe des fruits du Canarium schweinfurthii Engl Tropicultura, 22(2), 70-76.

Oswin, C. R. (1946). The kinetics of package life. III. The isotherm. Journal of Chemistry and Industry, 65, 419-421. http://dx.doi.org/10.1002/jctb.5000651216

Rao, M. A., \& Rizvi, S. S. H. (1995). Engineering Properties of Foods (Marcel Dekker Inc, New York, USA).

Ruegg, M. (1980). Calculation of the activity of water in sulphuric acid solutions at various temperature. Lebensmittel-Wissenchaft und Technology, 13, 22-24.

Sandoval, A. J., \& Barreiro, J. A. (2002). Water sorption isotherms of non-fermented cocoa beans. Journal of food engineering, 51, 119-123. http://dx.doi.org/10.1016/S0260-8774(01)00047-4

Saravacos, G. D., Tsiourvas, D. A., \& Tsami, E. (1986). Effect of temperature on thewater adsorption isotherms of sultana raisins, $J$ Food Sci, 51, 381-387. http://dx.doi.org/10.1111/j.1365-2621.1986.tb11135.x.

Smith, S. E. (1947). The sorption of water vapour by high polymers. Journal of the American Chemical Society, 69, 646. http://dx.doi.org/10.1021/ja01195a053

Rockland, L. B. (1969). Water activity and storage stability. Food Technology, 23, 1241-1251.

Talib, M. Z. M., Daud, W. R. W., \& Ibrahim, M. H. (1995). Moisture Desorption Isotherms of Cocoa Beans. American Society of Agricultural and Biological Engineers, Transactions of the ASABE, 38(4), 1153-1155. http://dx.doi.org/10.13031/2013.27933

Tsami, E., Maroulis, Z. B., Morunos-Kouris, D., \& Saravacos, G. D. (1990). Heat of sorption of water in dried fruits, Int J Food Sci Technol, 25, 350-359. http://dx.doi.org/10.1111/j.1365-2621.1990.tb01092.x

Tsami, E. (1991). Net Isosteric Heat of Sorption in Dried Fruits. Journal of Food Engineering, 14(4), 327-335. http://dx.doi.org/10.1016/0260-8774(91)90022-K

Vazquez, G., Chenlo, F., \& Moreira, R. (2003). Sorption isotherms of lupine at different temperatures. Journal of Food Engineering, 60, 449-452. http://dx.doi.org/10.1016/S0260-8774(03)00068-2 
Veltchev, Z. N., \& Menkov, N. D. (2000). Desorption Isotherms of Apples at Several Temperatures. Drying Technology, 18(4-5), 1127 -1137. http://dx.doi.org/10.1080/07373930008917759

Van den Berg, C. (1984). Description of water activity of foods for engineering purposes by means of the GAB model of sorption, In B. M. McKenna (Ed.), Engineering and Food, (Vol. 1, pp. 311-321). New York, USA: Elsevier Applied Science.

Van den Ben \& Bruin. (1981). Water activity and its estimation in food systems. In L. B. Rockland \& G. F. Steward (Eds.), Water Activity: Influences on Food Quality (pp. 147-177). New York, USA: Academic Press.

Wolf, W., Spiess, W. E. L., \& Jung, G. (1985). Standardization of isotherms measurements (cost-project 90 and 90 bis). In D. Stimatos \& J. L. Multon (Eds.), Properties of water in foods in relation to quality and stability (pp. 661-679). Dordrecht: Martinus Nijhoff Publishers. http://dx.doi.org/10.1007/978-94-009-5103-7_40

\section{Copyrights}

Copyright for this article is retained by the author(s), with first publication rights granted to the journal.

This is an open-access article distributed under the terms and conditions of the Creative Commons Attribution license (http://creativecommons.org/licenses/by/3.0/). 